\title{
SOCIAL CAPITAL AND RESOURCE MOBILIZATION DURING PANDEMIC: INSIGHT FROM JOGO TONGGO PROGRAM IN CENTRAL JAVA
}

Jurnal Analisa Sosiologi

Juli 2021, 10 (Edisi Khusus

ICOSAPS): $313-325$

\section{Retna Hanani $^{1}$, Amni Zarkasyi Rahman ${ }^{2}$, Yuliana Kristanto ${ }^{3}$}

\begin{abstract}
The impacts of the Covid19 pandemic are not only limited to the health sector. It also affects economic growth and more importantly our social fabrics. Due to its extensive impacts, governments especially in low-middleincome countries are facing tremendous challenges in mitigating covid19. In Indonesia, the government's efforts in mitigating the impact of covid19 have been criticized for being inadequate, ineffective, and too late. The number of covid19 victims has surpassed 70,000 cases and economic growth is contracted significantly. One important element of the government's effort during the pandemic is mobilizing social capital to support the government's efforts. Theoretically, community-based activities and mobilization of social capital during outbreaks are positive attributes. The emergence of volunteers and mutual aid initiatives are generally considered good examples of social capital mobilization. However, this article highlights a different angle to the relationship between social capital, community-based resource mobilization, and the pandemic. Looking at the implementation of the Jogo Tonggo program in Central Java, we argue that state mobilization does not always lead to positive resource mobilization in coping with the impact of covid19. We employ discourse network analysis to examine the implementation of the Jogo Tonggo program through news from a local newspaper in Central Java. From our research, we argue that despite the ambitious vision of Jogo Tonggo, it does not appear to be the main discourse at the societal level. Moreover, much of the implementation of the Jogo Tonggo program is top-down and does not invoke a deep level of participation from the community.
\end{abstract}

Keywords: social capital, resiliency, covid19, Jogo tonggo

\footnotetext{
Abstrak

Dampak pandemi covid19 tidak hanya terbatas pada sektor kesehatan, tetapi juga mempengaruhi pertumbuhan ekonomi dan yang lebih penting adalah tatanan sosial kita. Karena dampaknya yang luas, pemerintah terutama di negara berpenghasilan menengah ke bawah menghadapi tantangan yang luar

1,2,3, Departemen Administrasi Publik, FISIP Universitas Diponegoro

${ }^{1}$ r.hanani@live.undip.ac.id

Artikel yang diterbitkan Jurnal Analisa Sosiologi pada edisi khusus ICOSAPS ini telah memenuhi syarat-syarat karya ilmiah, diproses sama seperti pada penerbitan non edisi khusus (terbitan normal), dipresentasikan di International Conference on Social and Political Sciences (ICOSAPS) "Strengthening Resilient Society in the Disruptive Era "yang diselenggarakan oleh Fakultas Ilmu Sosial dan Politik Universitas Sebelas Maret Surakarta pada tanggal 7-8 Oktober 2020.
} 
biasa dalam menanggulangi COVID19. Di Indonesia misalnya, upaya pemerintah dalam menanggulangi dampak Covid19 dikritik karena kurang memadai, tidak efektif dan terlambat. Jumlah korban covid19 telah melampaui 70.000 kasus dan pertumbuhan ekonomi menurun secara signifikan. Salah satu elemen penting dari upaya pemerintah selama pandemi adalah memobilisasi komunitas untuk mendukung upaya pemerintah. Secara teoritis aktivitas berbasis komunitas dan mobilisasi modal sosial selama wabah adalah atribut positif. Munculnya relawan dan inisiatif gotong royong umumnya dianggap sebagai contoh yang baik dari mobilisasi modal sosial. Namun, artikel ini menyoroti sudut pandang yang berbeda tentang hubungan antara modal sosial, mobilisasi sumber daya berbasis komunitas, dan pandemi. Melihat implementasi program Jogo Tonggo di Jawa Tengah, kami berpendapat bahwa mobilisasi negara tidak selalu mengarah pada mobilisasi sumber daya yang positif dalam mengatasi dampak COVID-19. Kami menggunakan discourse analysis network (DNA) untuk mengkaji implementasi program Jogo Tonggo melalui berita dari koran lokal di Jawa Tengah. Dari penelitian kami, kami berpendapat bahwa terlepas dari visi Jogo Tonggo yang ambisius, program ini tampaknya tidak menjadi wacana utama di tingkat masyarakat. Terlebih lagi, banyak pelaksanaan program Jogo Tonggo yang top down dan tidak melibatkan partisipasi masyarakat.

Kata Kunci: modal sosial, ketahanan, covid19, jogo tonggo

\section{INTRODUCTION}

Covid19 has significantly impacted every aspect of our life. Until 31 August 2020 more than 25 million people around the world are infected with the virus and more than 800 people died from the virus. In addition to human loss, covid19 also has a great impact on the economy. The World Bank through The Global Economic Prospects for June 2020 outlines both the immediate and the near-term outlook for the pandemic's effects and the long-term harm it has caused to growth prospects. The baseline forecast foresees a 5.2 percent fall in global GDP by 2020, using market exchange rate weights - the worst global recession in decades, amid government unprecedented attempts to fight the fall with fiscal and monetary policy support. The deep recessions caused by the pandemic are expected to leave permanent scars over a longer period.

As a low-middle-income country (recently Indonesia has a new status as an upper-middle country), covid19 also has impacted the livelihoods of millions of people. In terms of human impacts, until 31 August 2020, Indonesia has 175.000 active covid19 cases and more than 7 thousand people have died due to the virus. Many scholars have argued that the government official number is far lower than the actual covid19 cases. Activists from Kawal Covid19, a volunteer-based organization that actively documenting the number of covid19 cases in Indonesia, argue that the actual 
number of covid19 cases in Indonesia is tripled than the government's official counts.

In addition to the human loss, covid19 has also impacted Indonesia's economic sector especially the tourism and poverty reduction sector. SMERU, a think tank on development issues, suggests that covid19 has driven Indonesia's economic growth down from the usual 5 percent to 1-4 percent growth in 2020. SMERU predicts that the poverty rate will rise from 9.2 percent in September 2019 to 9.7 percent by the end of 2020 under the mildest COVID-19 effect on economic development. This means 1.3 million more people are forced into poverty. The poverty rate will rise to 12.4 percent under the most extreme forecast, meaning that 8.5 million more people will become poor (Suryahadi, Al Izzati, and Suryardarma, 2020). The latter means that Indonesia's success in poverty reduction over the last decade will be wiped out. The consequence of this is that in addition to the current poor, Indonesia needs to extend its social welfare services to support the new poor.

For low and middle-income countries such as Indonesia, covid19 creates additional problems in an already precarious situation in which many LIDCs are situated. LIDCs including Indonesia have been hit since March 2020 by an unusual confluence of external shocks: a sharp contraction in real exports, lower export prices, particularly for oil, lower inflows of capital and remittances, and reduced income from the tourism sector. Domestically, while lockdowns and more mobility restrictions need to be implemented, many low and middle-income countries do not have sufficient financial capacity to perform such policy. A large proportion of the population in these countries live at subsistence levels with broad informal markets, limited institutional capability, and low incomplete registries. These conditions make implementing strict mobility intervention to the vulnerable become more challenging. In addition, governments have restricted fiscal resources to support the policy (Jaffrey, 2020).

Amid the scarce resources and limited government capacity, local and national governments rely on community support. Since the first presidential decree on the status of covid19 in Indonesia in March 2020, the role of local governments and communities are indispensable. In his speech at the beginning of the covid19 pandemic, President Joko Widodo, exclaims: "Following the law, this PSBB is determined by the Minister of Health in coordination with the Head of the Covid-19 Handling Task Force and regional heads. The legal basis is Law Number 6 of 2108 concerning Health Quarantine. The government has also issued a government regulation (Peraturan Pemerintah) on large-scale social restrictions and a Presidential Decree stipulating public health emergencies to carry out the mandate of this law."

Based on the Presidential mandate, local governments implement various policies to mitigate the impacts of Covid19 at the local level. 
Central Java stands out compared to other regions. The landmark of the policy is the decision of the Central Java Government to create a community-based policy to mitigate the impact of covid19 known as Jogo Tonggo. The policy differs from the usual government-centric intervention in other regions. In Jogo Tonggo, communities are actively mobilized to cope with the impact of covid19. The reasoning behind Jogo tonggo can be seen in the governor's remarks: "We in Central Java have allocated a budget of Rp 2.09 trillion for handling Covid-19 pandemic, consisting of Rp. 1.32 trillion for the implementation of the social safety net program, Rp. 183.5 billion for an economic safety net, and $\mathrm{Rp} 68.5$ billion for village financial assistance. Rp 425.14 billion for health facilities and Rp. 16.09 billion for the return of our migrant or PMI jobs. As well as Rp 1.65 billion for operations. But I realized that would not be enough. So in Central Java, we created the jogo tonggo movement. The movement to protect each other between neighbors. What must we protect? Take care of your neighbors' health by not going out of the house, wearing a mask, by keeping your distance. We protect the neighboring economy by buying their products".

The remark shows how Jogo Tonggo becomes the backbone of the covid19 strategy in Central Java. In the remark, Ganjar also explained the aims and personnel to implement the Jogo Tonggo program. According to Ganjar, The Jogo tonggo task force is not an organization formed from zero, but rather it consolidates and synergizes all activities of social group organizations. Ganjar Pranowo further claims: "We have human resources who are ready to implement this Jogo Tonggo consists of community activists".

Based on the ambitious vision of Jogo Tonggo and the vast human resource to implement the program, the article is interested to look at the implementation of Jogo Tonggo. We are interested to look at how Jogo Tonggo is perceived by the public in Central Java and to what extent the implementation of Jogo Tonggo has lived up to its ambition.

\section{RESEARCH METHOD}

In this paper, we examine news concerning the Jogo Tonggo program presented at two local newspapers in Central Java Province from March 2020 - July 2020. The newspapers are Suara Merdeka which circulates the whole region of Central Java Province and Radar Semarang which mostly covers news and events around Semarang only.

To generate data from the sources, we utilize Discourse Network Analysis. This study uses Discourse Network Analysis (DNA) software, a JAVA-based software that can identify a network of discourses from Jogo Tonggo stakeholders. The stakeholders consist of the Governor of Central Java, government actors, and community actors. 
The steps for processing data with DNA can be described as follows: the first step is coding statements from regional authority figures (hereinafter referred to as actors) or organizations that make discourses or statements; second, categorizing statements of actors; third, Coding the Actor's statement in a dummy variable (Yes / No) to show the Actor's approval or disagreement with the category being referred to; fourth, convert the results of the categorization into networks with the help of network-analytic software, namely Visone.

There are 5 basic types of discourse networks generated from DNA software: Affiliation Networks, Actor Congruence Networks, Conflict Networks, Concept Congruence Networks, and Dynamic Discourse Networks. Discourse Networks). However, because this study aims to identify the policy that is currently implemented, we only examine Affiliation Networks. The network was selected to compile the network map, organization, and actors.

\section{RESULT AND DISCUSSION}

The Role of the community during a pandemic is undeniably important. In disaster studies, the role of community is aimed to explain various processes to achieve a resilient society (Sanyal and Routray, 2016). As such, group resilience is defined as the collective capacity of a community or geographically specified region to cope with stressors and resume the routines of everyday life efficiently by coordinating aftershocks (Aldrich and Meyer, 2015). With rising losses from disasters, experts in disaster management have embraced various types of resilience as a method to resolve losses and recover from impacts. There are various approaches to study community resilience such as The National Disaster Recovery System of the Federal Emergency Management Agency, the Whole Community Approach to Emergency Management, the United Nations Making Cities Resilient Campaign, the Hyogo Framework for Action, and the National Health Security Strategy. All these approaches address the role of community resilience in their framework (Maghfiroh and Hanaoka, 2020).

Research on disasters has long understood that societies work together daily to survive and recover from devastating impacts (Melo Zurita et al., 2018). While disaster situations usually produce images of trained professionals as well as formal rescue operations, scholarship has shown that informal links, particularly neighbors, regularly serve as the actual first actor to help in the situation (Djalante, Shaw, and DeWit, 2020). Neighbors monitor other people's well-being nearby and offer urgent assistance in lifesaving. In the 1995 Kobe earthquake, for example, the majority of people who had been pulled out of the rubble of their collapsed homes were rescued by neighbors not firefighters or rescue workers. In conclusion, 
networks of individual and community social capital provide access to a range of services including information, assistance, financial resources, and childcare, along with emotional, and psychological support (Poortinga, 2012).

Social capital is defined by Louis Hanifan (1916) as goodwill, friendship, mutual affection, and social interaction between a group of individuals and families that form a unit of society (Emirbayer and Williams, 2005). The definition has since been embraced by many fields and generally describes how group engagement and interaction can have beneficial effects on individuals and the community. Bourdieu later defined social capital, together with economic, cultural, and symbolic capital, as one of four types of capital that collectively decide the path of our social life. In this context, social capital is defined as the amount of the actual or potential resources linked to ownership of a permanent network of relationships that are more or less institutionalized through mutual acquaintance or recognition. In the context of the pandemics, we are interested in reviewing social capital as a means to organize collective action such as Jogo Tonggo. Therefore, we look at theoretical and analytical studies related to resilience which has already listed several factors that could help neighborhoods tackle community problems related to disaster or pandemic (Djalante et al., 2020).

From the data examination, we show that through media reporting Jogo Tonggo started to be public discourse in mid-May 2020. At that time Jogo Tonggo was introduced as some kind of program to support the government's lack of resources to mitigate the impact of covid19 on the community. In the launch of Jogo Tonggo for example, Ganjar Pranowo said: "no matter how big the budget disbursed by the central and regional governments if the people are not careful it will be useless". Therefore, he asked the community to optimize 'Jogo tonggo'. Further, Ganjar Pranowo mobilized local wisdom and formed the Jogo Tonggo program to help people deal with the Covid-19 pandemic. According to him, the program was launched because assistance from the state during Covid-19 was certain to never be sufficient to meet the needs of the community. "The Jogo Tonggo program means looking after neighbors,".

As a program that helps society to cope with the impact of covid19, Ganjar explains that The Jogo Tonggo program also deals with health, social security, and entertainment matters. According to Ganjar Pranowo's remark, we can also see that Jogo Tonggo is developed based on the notion of gotong royong which has been popular among citizens as well as policymakers in Indonesia. According to Ganjar: "Jogo Tonggo will provide a food barn with land use so that food needs are fulfilled". Related to many of Jogo Tonggo activities, he said, this movement has been around for a long time and has since been revived. "It's like "gotong royong" cooperation in the community. I turn this on and it turns out well". 
To implement Jogo Tonggo, the provincial government relies on community actors such as PKK Cadres, women community activists (dasawisma), community safety group (Satlinmas), community health centers (Posyandu), and farming groups (Gapoktan). The government identifies 1,337,767 PKK cadres, 506,819 dasawisma, 230,782 Satlinmas, 228,142 posyandu cadres and 55,057 farmer groups. Further, he also mentions 39,045 village community empowerment cadres who are typical of the Central Java community that already assisted village empowerment programs, there are 7,527 village midwives, 3,370 village assistants, 8,229 Gapoktan, 1,123 Tagana and 5,413 extension workers, self-help, and 540 social welfare workers at the sub-district level who were also involved in the jogo tonggo program.

Even though Jogo Tonggo was the highlight of Ganjar's policy, the response to Jogo Tonggo program among policymakers and legislatures were not always positive. Some policymakers expressed their objection to the Jogo Tonggo program. According to a member of the National Awakening Party (Partai Kebangkitan Bangsa) of the Central Java Provincial DPRD, Achmad Fadlun, he considered that the "Jogo Tonggo" program was not as expected because its implementation was not relevant to the existing situation. His criticism was related to some delay in the financing of the Jogo Tonggo program that makes some of the program delivery delayed. The delayed delivery according to Fadlun was no longer relevant to citizens' needs as citizens' are already moving to new normal conditions.

From the available report, it was also difficult to track responses from the public. Response from the public only appears in the news outlet when the government delivers the Jogo Tonggo assistance kit. Even in the news related to the disbursement of the Jogo Tonggo kit, it was only the voice of officials that appeared in the news outlet. The example is the following: "The Central Java Provincial Government has started distributing Jogo Tonggo to all districts and cities. This assistance is expected to be a stimulant for the Jogo Tonggo Task Force at the sub-district and RT / RW levels to motivate the community to independently prevent COVID-19." In regional news, the face of citizens becomes even more limited. In Pekalongan, a region, Jogo Tonggo was only featured by statements from the District Chief (Bupati). The statement is the following: "the assistance of the Jogo Tonggo Kit was 27 packages for 27 urban villages. Each aid package contains 10 sets of protective gear (PPE) for civilians, 10 pairs of boots, 10 pairs of gloves, one automatic spryer, 1,000 pcs of 1000 cloth masks, 50 liters of hand sanitizer, 30 liters of disinfectant, one thermometer gun, one package of manuals technical, and one bag. The aid value is around Rp. 8 million. In general, similar to the Governor, district leaders such as Mayor of Pekalongan City, Saelany Machfudz, also said that the Jogo Tonggo Task Force was a movement based on solidarity from the 
people at the grassroots level to protect each other in all matters, especially the prevention of Covid-19 and its effects.

In the news outlet that we studied, similar to other regions, Jogo Tonggo appears as a remedy to overcome the government's lack of capacity to mitigate covid19. In Semarang for example, the Mayor of Semarang chose to implement Jogo Tonggo as an alternative to PSBB. His statement is: "Semarang Mayor Hendrar Prihadi chose Jogo Tonggo to curb the transmission rate of the Corona Virus (Covid-19) in his area. Later, the movement based on each RW will receive support from 48 joint patrol teams at the Jogo Tonggo monitoring post." With the implementation of Jogo Tonggo, Hendi explained that at the village (kelurahan) level they are allowed to carry out an area of quarantine with a portal using whatever tool available. The implementation of the Jogo Tonggo will later receive full support with the existence of the monitoring post. In total there are 16 monitoring posts prepared by the Government of Semarang. Every single monitoring post was guarded by three teams. The statement from Semarang Mayor is in line with the statement from Ganjar Pranowo on the spirit of Jogo Tonggo. Both the Mayor and the Governor believe that to cope with the impact of Covid19, a community should be at the forefront of the program. The statement of Ganjar is the following: "People should be at the forefront, armed with running water, soap, and masks. And implement the core strategy, stay home and keep your distance. Further, he also emphasizes the role of the village. "The basis is the village. Why? We can exercise restricted movement in smaller spaces because we can control it directly. If we want to set the larger mobility restriction such as PSBB, have we calculated and are ready? If not, we will first practice by taking actions such as PSBB. We will start changing the market starting tomorrow. Those who go there must wash their hands, they must wear a mask, or send them home, ".

We further examine the role of the public in the implementation of Jogo Tonggo. Based on our research we only find minor reporting on community activities. We found in Suara Merdeka 12 May 2020 reporting on community activities in accordance to Jogo Tonggo. In the article, the newspaper reported activities of Residents of RT002 / RW03, Jomblang Village, Semarang, Central Java, who have worked together to build public kitchens to meet the needs of residents affected by Covid-19. Within a day, hundreds of portions of food and drinks are distributed to local communities for free. Chairman of RW 03 Suryo Setiawan (51) said that the establishment of a public kitchen was started from concerns about the fate of hundreds of residents affected by the covid19 pandemic. "There are many workers here, starting from day laborers, microbus drivers, hotel employees, construction workers, rice sellers, and traders. So in the current condition, it is very important to have a public kitchen that can meet the needs of residents who are in trouble," Suryo hopes that public kitchen can ease the 
burden on residents affected by Covid-19. The most important thing, he said, is to maintain the spirit of Jogo Tonggo so that it can be a tradition among the residents as well as between residents in other villages. "We don't know how long the covid19 pandemic will last, so we will protect the spirit of Jogo Tonggo by preparing food barns from jimpitan and patrols. So the hope is that residents from other villages can also apply the same thing," he said. Until now, Jomblang Village already has two public kitchens which are managed independently.

We then code the qualitative data that we found in the news outlet with the hope that we could generate a general trend concerning Jogo Tonggo. We present the general trend of reporting on Jogo Tonggo by utilizing software visone. The result is the following graph 1 .

Graph 1. Result of Jogo Tonggo reporting

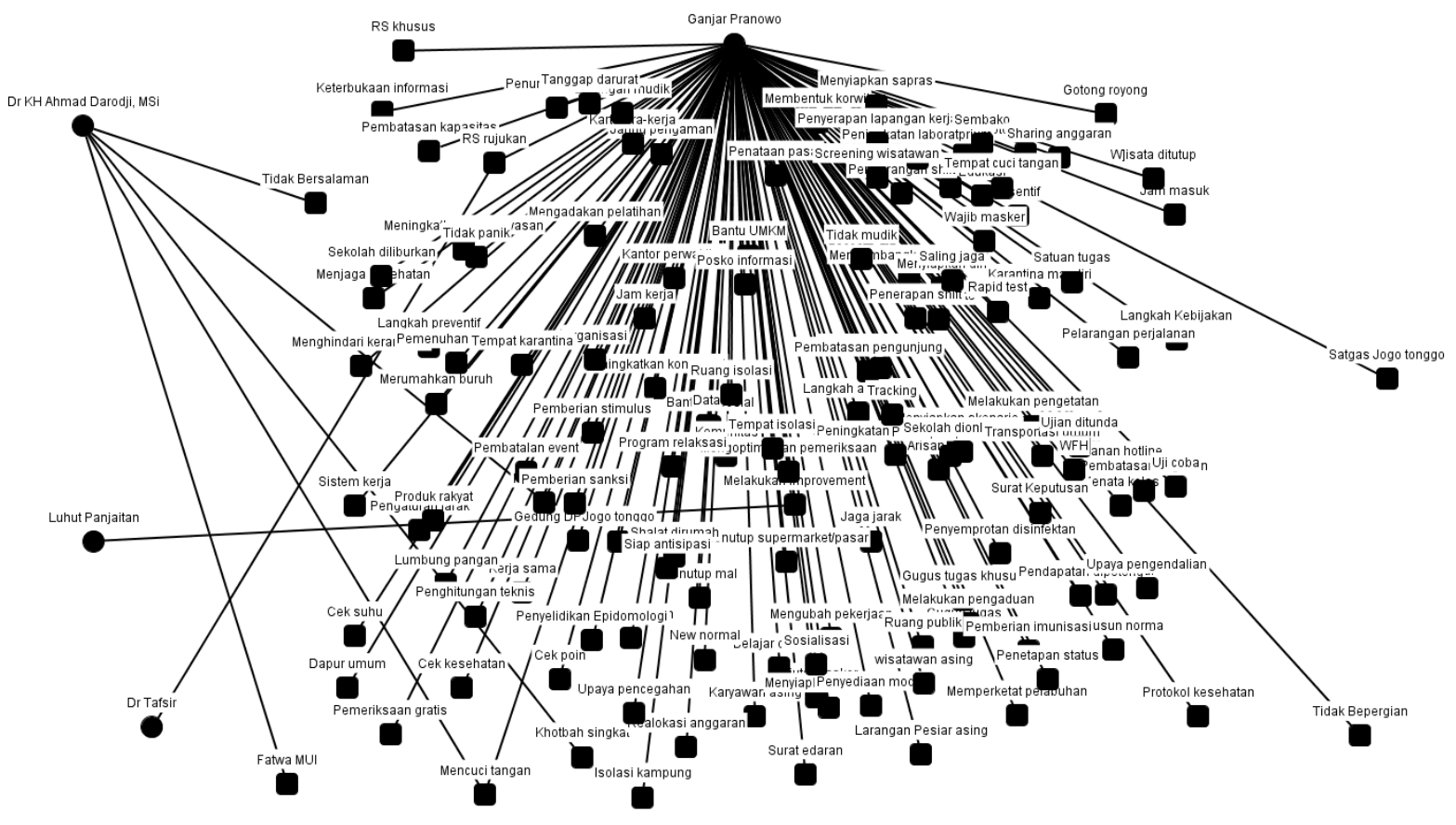

From the graph, we can see that indeed Jogo Tonggo was rarely mentioned and reported in the news outlet. By looking at the graph we can see that Jogo Tonggo was not part of major discourse even among the stakeholders. The news on Jogo Tonggo was buried under different reportage and statements from policymakers on covid19 issues that do not have a direct link with the Jogo Tonggo program. Surprisingly, even though Jogo Tonggo has been deemed as the backbone of the covid19 policy, policymakers themselves usually focus on health interventions such as health anticipation, the ban on the congregation, curfew, security, emergency efforts, and prevention. Looking at the graph we can conclude 
that despite the vision and ambition of Jogo Tonggo, Jogo Tonggo was rarely appear in public discourse.

To further examine the role of Jogo Tonggo we make the comparison with another community-based initiative called Sonjo in Yogyakarta. The comparison with other community initiatives is important to show that government-initiated and government-led community activities may not as effective as the government hopes for. Furthermore, as we explain later, the government-led community initiative may further reinforce the notion of limited government capacity in dealing with the impact of Covid-19.

Sonjo is a humanitarian movement focused on helping vulnerable communities at risk of being affected by the spread of Covid-19 in the Special Region of Yogyakarta. The word Sonjo (derived from Javanese) means friendship and specifically, Sonjo stands for Sambatan Jogja. Sambatan is a form of mutual assistance that is mostly done in rural areas in Java to build people's houses / public facilities. Sonjo is a medium to bring together the demand and supply side of humanitarian assistance to vulnerable and at-risk groups related to Covid19. The SONJO movement is based on three principles: a) empathy; b) solidarity, and c) mutual help "gotong royong". To introduce its activities to a wider audience, Sonjo uses internet hashtags such as \#OraAnaSingKeri or no one is left behind.

As part of its efforts to create a medium of information and mutual help, Sonjo facilitates help requests and help offers for humanitarian assistance through the Sonjo Whatsapp Group (WAG). Sonjo Whatsapp group was formed on Tuesday, March 24, 2020. As of 1 April 2020, Sonjo Whatsapp group reached 242 members. SONJO WAG has also developed into six WAGs, namely Sonjo HQ, Sonjo-Database, Sonjo-Media, Sonjo Pangan, Sonjo Inovasi, Sonjo-Legawa. Each Whatsapp group has a different function based on the issues discussed in the group. For instance, Sonjo HQ is a center for all Sonjo activities. This group accommodates all members of Sonjo's group. Sonjo-Database is a central administration and database to support the movement. In this Whatsapp Group, Sonjo members identify various problems reported by community members. The members fill out Google sheet forms to identify various programs of activities of the parties and the need for assistance from the community. SONJO-Media as information dissemination center and mass media network. SONJO-Pangan focuses on efforts to solve the problem of food fulfillment in DIY. The main purpose of Sonjo Pangan is to bring together various actors that could provide the food shortage problem including MSMEs. SONJO-Inovasi focuses on efforts to build prototypes of medical devices that previously had to be imported to be produced domestically. SONJO-Legawa, focuses on organizing social institutions to optimize the distribution of humanitarian aid. 
Even though Sonjo is a community-based organization, they also have a strong connection with policymakers including the local government of Yogyakarta. Sonjo regularly holds an online audience with the Governor of Yogyakarta, Sri Sultan Hamengkubuwono X, and other policymakers. The discussions with policymakers usually focus on various efforts to tackle the impact of Covid19 in Yogyakarta. In most of the meetings with the government, Sonjo also tries to ensure that the government incorporates all relevant policymakers such as the Regional Secretary of Yogyakarta; Head of the Yogyakarta Health Service, Chief Executive of BPBD DIY, and the Head of the DIY Communication and Informatics Office. During the meeting, Sonjo provides various inputs on the handling of Covid19 to the Governor of DIY. The input provided covers many aspects such as data collection, for example, how to manage bed data or data on shelter availability. Second, related to increased screening carried out, for example by using GeNose. The third input is related to the establishment of Covid19 response posts in RT / RW and district/city. Among the policymakers, the role of Sonjo is acknowledged and is considered as part of formal mechanisms to combat the impact of Covid19 in Yogyakarta.

Compared to the government-led initiative, Jogo Tonggo, community-based activities such as Sonjo may prove more effective and influential in mitigating the impact of Covid19. Through the WhatsApp group, Sonjo can help solve various problems as well as be able to bring together parties who need assistance and those who want to distribute aid (Nugroho and Negara, 2020). In its activities, Sonjo facilities exchanges of help demand such as from the hospitals, health workers, NGOs, academics, entrepreneurs, community groups, and others. At the same time, they also facilitate help supplies from fellow citizens as well as from aid organizations. The help supplies include academics, businessmen, NGOs, UMKM, community groups, LAZ, BUMN, BUMD, and others.

According to its founders, Sonjo is created as a market. It is an attempt to create a market for aid and those who want to be helped. For example, when someone needs PPE assistance then the member of the Sonjo group responded by channeling the needs to the different actor(s) who may be able to help. Sonjo, for example, was able to facilitate the exchange of help from an Australian entity that offered ventilator assistance.

Compared to Jogo Tonggo, genuine community initiatives such as Sonjo may not have grandiose programs. From the perspective of its founder, the most important driver is to fulfill small changes that can be made To help people survive amid the pandemic. Moreover, the founders of the community-led initiative fully realize the limit of government capacity to mitigate the impact of Covid19. According to the founder of Sonjo, even though the government has budgeted 405 trillion rupiahs to tackle Covid-19 and its recovery efforts, the war against Covid-19 cannot be entirely left to the government's responsibility. All elements of society must work together 
with the government, both at the central and regional levels, to tackle the impact of this pandemic.

Based on this comparison we can further argue that role of social capital is key to mobilize community responses to mitigate the impact of the Covid19 pandemic. In government-led initiatives such as Jogo Tonggo, social capital is created from a top-down perspective. As such, citizens may not sufficiently internalize the need for social solidarity as part of its key element. Furthermore, if we look at the everyday operation of Jogo Tonggo, the role of authoritative the figure such as community leaders (RT) is essential to lead the organization. This shows that government ledcommunity initiative relies heavily on state apparatuses and state resource to hold their activities.

\section{CONCLUSION}

Examining the implementation of the Jogo Tonggo program in Central Java, we argue that state mobilization does not always lead to positive resource mobilization in coping with the impact of covid19. We employ discourse network analysis to examine the implementation of the Jogo Tonggo program through news from local newspapers in Central Java. From our research, we argue that despite the ambitious vision of Jogo Tonggo, it does not appear to be the main discourse at the societal level. Moreover, much of the implementation of the Jogo Tonggo program is topdown and does not invoke a deep level of participation from the community.

\section{BIBLIOGRAPHY}

Aldrich, D. P. and Meyer, M. A. (2015). 'Social Capital and Community Resilience'. American Behavioral Scientist, 59(2), pp. 254-269. doi: 10.1177/0002764214550299.

Djalante, R. et al. (2020) 'Review and analysis of current responses to Covid-19 in Indonesia: Period of January to March 2020'. Progress in Disaster Science, (April), p. 100091. doi: 10.1016/j.pdisas.2020.100091.

Djalante, R., Shaw, R. and DeWit, A. (2020) 'Building resilience against biological hazards and pandemics: COVID-19 and its implications for the Sendai Framework'. Progress in Disaster Science, 6, p. 100080. doi: 10.1016/j.pdisas.2020.100080.

Emirbayer, M. and Williams, E. M. (2005) 'Bourdieu and Social Work'. Social Service Review, 79(4), pp. 689-724. doi: 10.1086/491604.

Jaffrey, S. (2020) Coronavirus Blunders in Indonesia Turn Crisis Into Catastrophe, Carnegie Endowment For International Peace. Available at: https://carnegieendowment.org/2020/04/29/coronavirus-blundersin-indonesia-turn-crisis-into-catastrophe-pub-81684 (Accessed: 26 
November 2020).

Maghfiroh, M. F. N. and Hanaoka, S. (2020) 'Multi-modal relief distribution model for disaster response operations', Progress in Disaster Science, 6. doi: 10.1016/j.pdisas.2020.100095.

Melo Zurita, M. de L. et al. (2018) 'Living with disasters: social capital for disaster governance', Disasters, 42(3), pp. 571-589. doi: 10.1111/disa.12257.

Nugroho, Y. and Negara, S. D. (2020) 'Singapore | 26 October 2020 COVID-19' s Impact on Micro , Small, \& Medium Enterprises and Tourism in Indonesia', (124), pp. 1-11.

Poortinga, W. (2012) 'Community resilience and health: The role of bonding, bridging, and linking aspects of social capital', Health and Place, 18(2), pp. 286-295. doi: 10.1016/j.healthplace.2011.09.017.

Sanyal, S. and Routray, J. K. (2016) 'Social capital for disaster risk reduction and management with empirical evidence from Sundarbans of India', International Journal of Disaster Risk Reduction, 19, pp. 101-111. doi: 10.1016/j.ijdrr.2016.08.010.

Suryahadi, A., Al Izzati, R. and Suryadarma, D. (2020) 'The Impact of COVID-19 Outbreak on Poverty: An Estimation for Indonesia (Draft)', SMERU Working Paper, April, pp. 1-20. Available at: http://smeru.or.id/en/content/impact-covid-19-outbreak-povertyestimation-indonesia. 